\title{
ANTIMICROBIAL ACTIVITIES OF SUCCESSIVE SOLVENT EXTRACTS OF ALBIZIA LEBBECK AND SOLANUM SEAFORTHIANUM AGAINST SOME HUMAN PATHOGENIC MICROORGANISMS
}

\author{
HOSUR NARAYANAPPA VENKATESH, DEVIHALLI CHIKKAIAH MOHANA* \\ Department of Microbiology and Biotechnology, Bangalore University, Jnana Bharathi, Bengaluru, Karnataka, India. \\ Email: mohanadc@gmail.com
}

Received: 20 February 2019; Revised and Accepted: 4 May 2019

\begin{abstract}
Objective: The continuous emergence of multidrug resistance bacteria and yeast, and the negative impact of synthetic preservatives have led to an increased interest in the use of plant extracts as alternative antimicrobial agents. In the present investigation, the antimicrobial activity of successive solvent extracts of Albizia lebbeck and Solanum seaforthianum has been evaluated against human pathogenic bacteria and yeast.
\end{abstract}

Methods: The disc diffusion method was employed for determination of the zone of inhibitions (ZOIs) and twofold broth dilution technique was employed for determination of minimal inhibitory concentrations, and minimal bactericidal/fungicidal concentrations.

Results: Among the successive solvent extracts tested, methanol extracts of both A. lebbeck and S. seaforthianum showed highest antibacterial activity with ZOIs ranged between 10.0 and $20.4 \mathrm{~mm}$ at $1 \mathrm{mg} /$ disc followed by ethanol (ZOIs 8.1-17.6 mm). The petroleum ether, toluene, and chloroform extracts showed the least activity. The highest activity was observed against Streptococcus faecalis, whereas the least activity was observed against Pseudomonas aeruginosa.

Conclusion: The broad-spectrum antimicrobial activity of methanol extract of $A$. lebbeck and S. seaforthianum could be explored as antimicrobial agents for the management of pathogenic bacteria and yeast.

Keywords: Albizia lebbeck, Solanum seaforthianum, Antimicrobial activity, Successive solvent extracts, Disc diffusion techniques.

(C) 2019 The Authors. Published by Innovare Academic Sciences Pvt Ltd. This is an open access article under the CC BY license (http://creativecommons. org/licenses/by/4. 0/) DOI: http://dx.doi.org/10.22159/ajpcr.2019.v12i6.32706

\section{INTRODUCTION}

Infectious diseases caused by many pathogenic bacteria and yeast are a major problem despite the tremendous achievement in human health care. According to the WHO statement, infectious diseases are the world's leading cause of premature death, and also approximately 17 million people die from infectious diseases annually [1]. These populations include infants and children, elderly peoples, pregnant women, people taking certain kinds of medications and also immune suppressed patient, such as cancer patients, ICU patients, and diabetic patients [2,3]. Some of the multidrug-resistant (MDR) pathogenic microbes commonly reported worldwide are Staphylococcus aureus, Salmonella typhimurium, Escherichia coli, Klebsiella pneumoniae, and Candida albicans $[4,5]$. Even though many pharmacological industries have produced a large number of new antibiotics in the last two decades, the continuous increase of drug-resistant pathogens is a big challenge for the treatment of infectious diseases [6]. Hence, there is a need to search for alternate effective and eco-friendly strategies. Medicinal plants have been used by humans since time immemorial for different ailments, and they also provided many valuable drugs on antimicrobial, antitumor, antidiabetic, antihypertensive, antimalarial, antioxidant, anti-inflammatory, antimutagenic, analgesic, and cardiovascular properties $[7,8]$. Medicinal plants are the richest bioresource of drugs of traditional medicines as well as modern medicines, and also they have provided many pharmaceutical intermediates and chemical entities for discovery and development of novel drugs $[9,10]$. Further, they possess great potential in the field of biomedicine as they effectively destroy several bacterial, fungal, and viral pathogens [11,12]. Among the estimated 250,000-500,000 plant species, only a smaller percentage $(<10 \%)$ was subjected to pharmacological evaluation [13]. Considering these, the present investigation was undertaken and evaluates the antimicrobial activity of Albizia lebbeck belongs to the family Leguminosae and Solanum seaforthianum belongs to the family Solanaceae.

\section{METHODS}

Plant material collection and authentication

Fresh leaves of A. lebbeck and S. seaforthianum were collected from the Southern part of Karnataka (India) during 2014-2017. The plant samples were authenticated by Dr. Seetharam, Professor, Department of Biological Sciences, Bengaluru University, Bengaluru, India, and the authenticated voucher specimens were deposited in the Department of Microbiology and Biotechnology, Bangalore University, Bengaluru, along with a proper voucher number (Voucher number: BUB/MB-BT/ DCM/DST-SERB/1/28/2014-17).

Preparation of successive solvent extracts from selected plants The plants, namely, A. lebbeck and S. seaforthianum showed promising antimicrobial activity in the aqueous extract were subjected to successive solvent extraction following the procedure of Ayoub and Hamid [14]. $50 \mathrm{~g}$ of shade-dried and finely powdered of each plant material was filled in the thimble and extracted successively with $200 \mathrm{ml}$ of petroleum ether, toluene, chloroform, methanol and ethanol using a Soxhlet extractor to colorless extract obtained at the top of the extractor. Each solvent extract was concentrated separately under reduced pressure using a rotary flash evaporator (Superfit, Mumbai, India), and subjected for antimicrobial activity evaluation at desired different concentrations.

\section{Antimicrobial activity evaluation}

Test microorganisms

Nine human pathogenic microorganisms, namely, E. coli (National Collection of Industrial Microorganisms [NCIM] 2065), K. pneumoniae (NCIM 2957), Proteus vulgaris (NCIM 2027), Pseudomonas aeruginosa (NCIM 5031), Salmonella typhi (NCIM 2051), S. aureus (NCIM 2079), Streptococcus faecalis (NCIM 5025), C. albicans (NCIM 3471), and 
Cryptococcus neoformans (NCIM 3541) were collected from NCIM, Pune, India. All the tested bacteria and yeast were maintained on Mueller-Hinton agar (MHA) and malt extract-glucose-yeast extract-peptone-agar (MGYPA), respectively. $24 \mathrm{~h}$ old bacterial and $48 \mathrm{~h}$ old yeast cultures were used as test organisms.

\section{Antimicrobial activity assay}

The antibacterial and anti-yeast activities of successive solvent extracts of $A$. lebbeck and S. seaforthianum were evaluated against human pathogenic seven bacterial species and two yeast species by disc diffusion method following the procedure of Wikler, [15]. Briefly, $100 \mu \mathrm{l}$ of each bacterial inoculum $\left(10^{8} \mathrm{CFU} / \mathrm{ml}\right)$ and yeast inoculum $\left(10^{6} \mathrm{CFU} / \mathrm{ml}\right)$ were separately spread on MHA for bacterial species and MGYPA for yeast species and allowed to dry for $10 \mathrm{~min}$. Four layered $6 \mathrm{~mm}$ sterilized paper discs (Whatman No. 1) impregnated separately with different successive solvent extract $(1 \mathrm{mg} / \mathrm{disc})$ was placed on the surface of pre-inoculated MHA and MGYPA plates. The plates were kept for $1 \mathrm{~h}$ for extract diffusion at $4^{\circ} \mathrm{C}$; then all the treatments were incubated at $37^{\circ} \mathrm{C}$ for $24 \mathrm{~h}$ for bacteria and $28 \pm 2^{\circ} \mathrm{C}$ for $48 \mathrm{~h}$ for yeast. The disc impregnated with the same amount DMSO served as a negative control. The synthetic erythromycin $(15 \mu \mathrm{g} / \mathrm{disc})$ and fluconazole $(25 \mu \mathrm{g} / \mathrm{disc})$ served as a positive control for bacteria and, yeast, respectively. After incubation, antimicrobial activity was determined by measuring the diameter of zone of inhibitions (ZOIs) in millimeters (mm).

Determination of minimum inhibitory concentrations (MICs) and minimum bactericidal/fungicidal concentrations (MBCs/MFCs)

The MICs and MBCs of methanol extracts of A. lebbeck and $S$. seaforthianum were determined using a broth microdilution technique following the procedure of Prakash et al. [16] with some modification. Briefly, $200 \mu \mathrm{l}$ of twofold serially diluted each methanol extract in MHB and MGYPB (0.031-2.0 mg/ml) was added separately to the wells of a sterile 96-well microtiter plate, inoculated with $15 \mu \mathrm{l}$ of bacteria $\left(10^{8} \mathrm{cells} / \mathrm{ml}\right)$, yeast $\left(10^{6} \mathrm{cell} / \mathrm{ml}\right)$, and fungal spore suspension $\left(10^{4} \mathrm{spores} / \mathrm{ml}\right)$, respectively. The inoculated plates were incubated at $37 \pm 2^{\circ} \mathrm{C}$ for $24 \mathrm{~h}$ for bacteria and $30 \pm 2^{\circ} \mathrm{C}$ for $48 \mathrm{~h}$ for yeast. After the incubation, $50 \mu \mathrm{l}$ of iodonitrotetrazolium chloride (INT-2 $\mathrm{mg} / \mathrm{ml}$ ) was added into each well of a microtiter plate and incubated further for another $30 \mathrm{~min}$ at respective temperatures as mentioned above. The pale yellow-colored INT was reduced to a pink color which indicated the presence of microbial viability, while the yellow color remained the same indicates the microbial growth inhibition. The lowest concentration required to reduce the intensity of the pink color was considered as MIC, and the lowest concentration at which yellow color remains unchanged considered as $\mathrm{MBC} / \mathrm{MFC}$.

\section{Statistical analysis}

The experiments were performed in triplicate and values were expressed as means \pm standard error. Analysis of variance was conducted, and the differences between values were tested for deviation significance by ANOVA with the SPSS 20 program (IBM, Armonk, NY, USA). Differences at $\mathrm{p} \leq 0.05$ were considered statistically significant.

\section{RESULTS}

The antimicrobial activity of successive solvent extracts of A. lebbeck and $S$. seaforthianum was evaluated and the obtained results are presented in Tables 1 and 2. The negative control DMSO did not show antimicrobial activity against the tested bacteria and yeast. Among the successive solvent extracts tested, methanol extracts of both A. lebbeck and $S$. seaforthianum showed highest antimicrobial activity with ZOIs ranged between 10.0 and $20.4 \mathrm{~mm}$ at $1 \mathrm{mg} /$ disc followed by ethanol extract (ZOIs 8.1-17.6 mm). Tukey's HSD data analysis revealed that

Table 1: Antimicrobial activity of successive solvent extracts of Albizia lebbeck against some human pathogenic bacteria and yeast

\begin{tabular}{|c|c|c|c|c|c|c|c|c|}
\hline \multirow[t]{2}{*}{ Test microbes } & \multicolumn{5}{|c|}{ Solvent extracts $(1 \mathrm{mg} / \mathrm{disc})$} & \multicolumn{2}{|c|}{$\begin{array}{l}\text { Methanol extract } \\
(\mathrm{mg} / \mathrm{ml})\end{array}$} & \multirow[t]{2}{*}{$\begin{array}{l}\text { Erythromycin/ } \\
\text { Fluconazole }\end{array}$} \\
\hline & PE & TE & CE & ME & EE & MIC & MFC & \\
\hline Escherichia coli & $7.2 \pm 0.4$ & $6.8 \pm 0.3$ & $10.6 \pm 0.5$ & $11.8 \pm 0.6$ & $10.1 \pm 0.6$ & 0.25 & 1.0 & $11.36 \pm 0.5$ \\
\hline Klebsiella pneumoniae & $9.0 \pm 0.7$ & $8.2 \pm 0.4$ & $12.1 \pm 0.7$ & $13.5 \pm 0.7$ & $9.7 \pm 0.5$ & 0.125 & 0.5 & $15.27 \pm 0.8$ \\
\hline Proteus vulgaris & $8.6 \pm 0.5$ & $6.3 \pm 0.3$ & $7.8 \pm 0.6$ & $10.8 \pm 0.8$ & $9.2 \pm 0.7$ & 0.25 & 2.0 & $9.48 \pm 0.4$ \\
\hline Pseudomonas aeruginosa & $6.7 \pm 0.6$ & $0 \pm 0.0$ & $7.2 \pm 0.3$ & $10.0 \pm 0.4$ & $8.9 \pm 0.6$ & 0.5 & 2.0 & $11.32 \pm 0.3$ \\
\hline Salmonella typhi & $9.5 \pm 0.6$ & $8.5 \pm 0.7$ & $13.4 \pm 0.8$ & $13.9 \pm 0.4$ & $11.4 \pm 0.5$ & 0.125 & 0.5 & $20.18 \pm 0.7$ \\
\hline Staphylococcus aureus & $10.2 \pm 0.8$ & $9.8 \pm 0.6$ & $14.6 \pm 0.5$ & $15.3 \pm 0.5$ & $13.4 \pm 0.6$ & 0.062 & 0.25 & $18.62 \pm 0.6$ \\
\hline Streptococcus faecalis & $12.8 \pm 0.5$ & $10.5 \pm 0.7$ & $17.2 \pm 0.7$ & $19.8 \pm 0.3$ & $17.6 \pm 0.4$ & 0.031 & 0.25 & $20.95 \pm 0.8$ \\
\hline Candida albicans & $10.6 \pm 0.3$ & $8.4 \pm 0.5$ & $9.5 \pm 0.6$ & $14.7 \pm 0.9$ & $13.7 \pm 0.5$ & 0.125 & 0.5 & $15.45 \pm 0.6$ \\
\hline Cryptococcus neoformans & $12.3 \pm 0.4$ & $10.2 \pm 0.5$ & $11.4 \pm 0.8$ & $16.5 \pm 0.7$ & $15.2 \pm 0.6$ & 0.062 & 0.25 & $17.69 \pm 0.5$ \\
\hline
\end{tabular}

PE: Petroleum ether extract, TE: Toluene extract, CE: Chloroform extract, ME: Methanol extract, EE: Ethanol extract. Erythromycin (15 $\mu \mathrm{g} /$ disc) and

Fluconazole $(25 \mu \mathrm{g} / \mathrm{disc})$ served as a positive control for bacteria and yeast, respectively. Data given are the mean of three replicates \pm standard error ( $<0.05)$. No activity was observed around DMSO control discs, MIC: Minimum inhibitory concentrations, MFC: Minimum fungicidal concentrations

Table 2: Antimicrobial activity of successive solvent extracts of Solanum seaforthianum against some human pathogenic bacteria and yeast

\begin{tabular}{|c|c|c|c|c|c|c|c|c|}
\hline \multirow[t]{2}{*}{ Test bacteria } & \multicolumn{5}{|c|}{ Solvent extracts $(1 \mathrm{mg} / \mathrm{disc})$} & \multicolumn{2}{|c|}{ Methanol extract $(\mathrm{mg} / \mathrm{ml})$} & \multirow[t]{2}{*}{ Erythromycin/fluconazole } \\
\hline & PE & TE & CE & ME & $\mathbf{E E}$ & MIC & MFC & \\
\hline Escherichia coli & $0.0 \pm 0.0$ & $0.0 \pm 0.0$ & $0.0 \pm 0.0$ & $11.2 \pm 0.4$ & $9.5 \pm 0.3$ & 0.25 & 2.0 & $11.36 \pm 0.5$ \\
\hline Proteus vulgaris & $0.0 \pm 0.0$ & $0.0 \pm 0.0$ & $0.0 \pm 0.0$ & $10.6 \pm 0.6$ & $8.1 \pm 0.3$ & 0.5 & 2.0 & $9.48 \pm 0.4$ \\
\hline Pseudomonas aeruginosa & $0.0 \pm 0.0$ & $0.0 \pm 0.0$ & $0.0 \pm 0.0$ & $13.4 \pm 0.7$ & $9.8 \pm 0.7$ & 0.25 & 2.0 & $11.32 \pm 0.3$ \\
\hline Salmonella typhi & $0.0 \pm 0.0$ & $0.0 \pm 0.0$ & $7.8 \pm 0.4$ & $14.5 \pm 0.6$ & $9.00 \pm 0.3$ & 0.25 & 1.0 & $20.18 \pm 0.7$ \\
\hline Staphylococcus aureus & $0.0 \pm 0.0$ & $0.0 \pm 0.0$ & $9.8 \pm 0.8$ & $15.3 \pm 0.5$ & $11.5 \pm 0.8$ & 0.125 & 0.5 & $18.62 \pm 0.6$ \\
\hline Streptococcus faecalis & $0.0 \pm 0.0$ & $0.0 \pm 0.0$ & $10.2 \pm 0.4$ & $20.4 \pm 0.8$ & $15.2 \pm 0.4$ & 0.062 & 0.25 & $20.95 \pm 0.8$ \\
\hline Candida albicans & $8.2 \pm 0.4$ & $6.4 \pm 0.5$ & $8.6 \pm 0.5$ & $13.2 \pm 0.7$ & $12.1 \pm 0.5$ & 0.125 & 0.5 & $15.45 \pm 0.6$ \\
\hline Cryptococcus neoformans & $9.8 \pm 0.6$ & $8.0 \pm 0.7$ & $9.5 \pm 0.8$ & $15.7 \pm 0.6$ & $13.4 \pm 0.6$ & 0.062 & 0.25 & $17.69 \pm 0.5$ \\
\hline
\end{tabular}

PE: Petroleum ether extract, TE: Toluene extract, CE: Chloroform extract, ME: Methanol extract, EE: Ethanol extract. Erythromycin (15 $\mu \mathrm{g} /$ disc) and

Fluconazole $(25 \mu \mathrm{g} / \mathrm{disc})$ served as a positive control for bacteria and yeast respectively. Data given are the mean of three replicates \pm standard error ( $<0.05)$. No activity was observed around DMSO control discs, MIC: Minimum inhibitory concentrations, MIC: Minimum inhibitory concentrations, MFC: Minimum fungicidal concentrations 
the petroleum ether, toluene and chloroform extracts showed the least activity against tested bacteria and yeast. The obtained results confirm that the active compounds which are responsible for antimicrobial activity are more soluble in the methanol extract followed by ethanol but least soluble in toluene.

The methanol extract which showed the highest antimicrobial activity was selected for MICs and MBCs/MFCs value determination using the broth dilution technique. The MICs and MBCs/MFCs value ranged between 0.031 and 0.5 and 0.25 and $2.0 \mathrm{mg} / \mathrm{ml}$, respectively. Among the bacteria tested, Streptococcus faecalis was observed as more susceptible bacteria with least MIC and MBC values, whereas E. coli and $P$. aeruginosa were as observed more resistant bacteria with highest MICs and MBCs values.

\section{DISCUSSION}

The present study clearly confirms that Gram-positive bacteria are more susceptible than Gram-negative bacteria; this is due to the presence of extra outer lipopolysaccharides cell wall in Gram-negative bacteria, which restrict extract penetration into the bacterial cell. On a comparative evaluation with synthetic antibiotics, the antibacterial activity of methanol extracts of A. lebbeck and S. seaforthianum was comparable with the synthetic antimicrobial agent's erythromycin and fluconazole. The review of literature revealed that the extracts of $A$. lebbeck and S. seaforthianum showed antimicrobial, antioxidant, antidiabetic, antimalarial, antiarthritic, and anti-allergic properties [17-27]. Ali et al. [17] from Bangladesh evaluated the antimicrobial and antioxidant activity of petroleum ether, ethyl acetate and methanol extracts of $A$. lebbeck against B. subtilis, S. aureus, V. mimicus, S. typhi, S. dysenteriae, C. arrizae, and A. niger. Malla et al. [21] reported that the methanolic extract of stem bark of $A$. lebbeck showed antimicrobial activity against $E$. coli and $S$. aureus. Siahpoosh et al. [20] reported that the methanolic extract of $A$. lebbeck showed moderate antioxidant activity. Xavier et al. [27] reported that the methanol extracts of $S$. seaforthianum showed promising inhibitory activity. Although the antimicrobial activity has been previously reported, there are no reports on antimicrobial activities of successive solvent extracts of $A$. lebbeck and $S$. seaforthianum against a broad range of bacteria and yeast. We are the $1^{\text {st }}$ time to report broad-spectrum antimicrobial activity of successive solvent extracts of A. lebbeck and S. seaforthianum.

\section{CONCLUSION}

The continuing emergence of MDR human pathogenic microbes and undesirable side effects caused by many currently available synthetic drugs have been collectively necessitated to search for new and broadspectrum alternative antibacterial agents. The promising antimicrobial activities of methanol extract of $A$. lebbeck and S. seaforthianum might be a prospective source as alternative antimicrobial agents for the management of pathogenic microorganisms.

\section{ACKNOWLEDGMENT}

The authors wish to thank the University Grants Commission-NFHE, and UGC-SAP-DRS-II phase, New Delhi, India, for financial support.

\section{AUTHORS' CONTRIBUTIONS}

Design, experimental part of the work and writing of the manuscript were done by the first author Dr. Venkatesh, H. N. The design of the work and correction of the manuscript were done by the corresponding author Dr. D. C. Mohana.

\section{CONFLICTS OF INTEREST}

No potential conflicts of interest were reported by the authors.

\section{REFERENCES}

1. Li XZ, Plesiat P, Nikaido H. The challenge of efflux-mediated antibiotic resistance in gram-negative bacteria. Clin Microbiol Rev
2015;28:337-418.

2. $\mathrm{Xu} Z \mathrm{ZQ}$, Flavin MT, Flavin J. Combating multidrug-resistant gram-negative bacterial infections. Expert Opin Investig Drugs 2014;23:163-82.

3. Adley CC, Ryan MP. The Nature and Extent of Foodborne Disease. Antimicrobial Food Packaging. San Diego: Academic Press; 2016. p. 1-10.

4. van Duin D, Paterson DL. Multidrug-resistant bacteria in the community: Trends and lessons learned. Clin Infect Dis 2016;30:377-90.

5. Chandar B, Ramasawamy MK. Evaluation of antioxidant, antibacterial activity of ethanolic extract in the leaves of Combretum albidum and gas chromatography-mass spectrometry analysis. Asian J Pharm Clin Res 2016;9:325-9.

6. Zheng W, Sun W, Simeonov A. Drug repurposing screens and synergistic drug-combinations for infectious diseases. Br J Pharmacol 2018;175:181-91.

7. Sandeep, Mittal A. Evaluation of antimicrobial and antioxidant activity of isolated constituents from areal part of Cuscuta reflexa Roxb. Plant Asian J Pharm Clin Res 2018;11:187-90.

8. Newman DJ, Cragg GM. Natural products as sources of new drugs from 1981 to 2014. J Nat Prod 2016;79:629-61.

9. Hosseinzadeh S, Jafarikukhdan A, Hosseini A, Armand R. The application of medicinal plants in traditional and modern medicine: A review of Thymus vulgaris. Int J Clin Med 2015;6:635-42.

10. Arunkumar K, Chandrashekar KR. Phytochemical evaluation and in vitro antimicrobial and antioxidant studies of leaf and stem bark extracts of Polyalthia fragrans (Dalz.) bedd-an endemic species of Western Ghats. Int J Pharm Pharm Sci 2017;9:20-4.

11. Azalework HG, Sahabjad A, Arshad M, Malik T. The phytochemical investigation, GC-MS profile and antimicrobial activity of a medicinal plant Ruta graveolens L. From Ethiopia. Int J Pharm Pharm Sci 2017;9:29-34.

12. Calo JR, Crandall PG, O'Bryan CA, Ricke SC. Essential oils as antimicrobials in food systems a review. Food Control 2015;54:111-9.

13. Chikezie PC, Ojiako OA. Herbal medicine: Yesterday, today and tomorrow. Altern Integr Med 2015;4:1-5.

14. Ayoub IM, Hamid AS. Phytochemical screening and antimicrobial activity of Thuja occidentalis seeds extracts against the isolated common skin infecting microorganisms. Int J Pharm Pharm Sci 2017;9:131-4.

15. Wikler MA. Methods for dilution antimicrobial susceptibility tests for bacteria that grow aerobically: Approved standard. CLSI (NCCLS) 2006;26:M7-A7.

16. Prakash B, Mishra PK, Kedia A, Dubey NK. Antifungal, antiaflatoxin and antioxidant potential of chemically characterized Boswellia carterii Birdw essential oil and it's in vivo practical applicability in preservation of Piper nigrum L. fruits. LWT-Food Sci Technol 2014;56:240-7.

17. Ali MT, Haque ST, Kabir ML, Rana S, Haque ME. A comparative study of in vitro antimicrobial, antioxidant and cytotoxic activity of Albizia lebbeck and Acacia nilotica stem bark. Bull Fac Pharm Cairo Univer 2018;56:34-8.

18. Cos P, Janssens J, Piñón A, Cuesta-Rubio O, Yglesias-Rivera A, DíazGarcía A, et al. Efficacy of four Solanum spp. Extracts in an animal model of cutaneous leishmaniasis. Medicines (Basel) 2018;5:1-11.

19. Ahmed D, Kumar V, Sharma M, Verma A. Target guided isolation, in-vitro antidiabetic, antioxidant activity and molecular docking studies of some flavonoids from Albizzia Lebbeck Benth. bark. BMC Complement Altern Med 2014;14:1-12.

20. Siahpoosh A, Mehrpeyma M. Antioxidant effects of Albizia lebbek and Prosopis julifora barks. Int J Bio Sci 2014;5:273-84.

21. Malla S, Shrotri CK, Jain R. Antimicrobial, phytochemical and antioxidant screening of leaves and stem bark from Albizia lebbeck (1). Int J Pharm Bio Sci 2014;5:259-70.

22. Zia-Ul-Haq M, Ahmad S, Qayum M, Ercişli S. Compositional studies and antioxidant potential of Albizia lebbeck (L.) Benth. Pods and seeds. Turk J Biol 2013;37:25-32.

23. Seyydnejad SM, Niknejad M, Darabpoor I, Motamedi H. Antibacterial activity of hydroalcoholic extract of Callistemon citrinus and Albizia lebbeck. Am J Appl Sci 2010;7:13-6.

24. Rahul C, Pankaj P, Sarwan SK, Mahesh JK. Phytochemical screening and antimicrobial activity of Albizzia lebbeck. J Chem Pharm Res 2010;2:476-4.

25. Venkatesh P, Mukherjee PK, Kumar NS, Bandyopadhyay A, Fukui H, Mizuguchi $\mathrm{H}$, et al. Anti-allergic activity of standardized extract of Albizia lebbeck with reference to catechin as a phytomarker. Immunopharmacol Immunotoxicol 2010;32:272-6.

26. Pathak N, Gohil P, Patel NB, Kasture S, Jivani N, Bhalodia Y. Curative effect of Albizia lebbeck methanolic extract against adjuvant arthritis-with special reference to bone erosion. Int J Pharm Sci Drug Res 2009;1:183-7.

27. Xavier TF, Kumar PN, Auxillia AS, Kannan M. In vitro growth inhibition of pathogenic bacteria by Solanum seaforthianum L. Asian J Plant Sci Res 2013;3:70-6. 